\title{
The Multi-Ethnic and Multi-Religious Transformation of the Largest Diocese in the World: The Church of Milan and the "Synod from the Peoples"
}

\author{
Laura Zanfrini and Luca Bressan
}

Held in the middle of the largest refugee crisis of our time since the end of World War II, while the city of Milan was dealing with the arrival of thousands of desperate -yet filled with hope- people, the minor Synod was immediately regarded as an initiative with prophetic meaning. ${ }^{1}$

The Synod is the instrument through which the Catholic Church enables each Diocese, convened in a formal gathering under the rule of the respective Bishop, to better define its mission to both announce and be a witness to the Christian faith. The recently appointed Archbishop Mons. Delpini chose to start the highly challenging rewriting process of the previous Diocesan Synod (the $47^{\text {th}}$ ) with the chapter on the Pastorale degli Esteri ${ }^{2}$ (literally "Pastoral of the Abroads", that is Pastoral of Foreign People) and took the occasion to remind the Church of its daily duty to be a witness to the Gospel. Through this Synod, the Church was reminded of the importance of practicing hospitality "we can find ourselves welcoming angels without even knowing it"3_ and was further encouraged to become a "Church from the People", thus fulfilling the ultimate aim of Catholicism.

This Church, as we will illustrate in this chapter, reflects the transformation of a city that has been changing considerably since the previous Synod, which dates back to the 1990s. In fact, both the Church and the city of Milan are facing the urgency to find their own identity. In this search, it is safe to say that the

1 This chapter is a translation, with minor changes, of an essay already published in an Italian version: Zanfrini L., Bressan L., 2018.

2 The previous Synod that took place in Milan was convened by Cardinal Carlo Maria Martini and was concluded in 1995. While the latter was meant to outline the general characteristics of the local Church, the one launched by Mons. Mario Delpini aimed at redefining every single trait of it. Such redefinition began with the examination of the trait that, in the past few decades, has been undergoing the most changes, due to the arrival in Milan of many people from very different places of the world.

3 Letter to the Hebrews, $13,2$. 
Christian roots preserved by the Ambrosian rite -some kind of "Oriental echo in the West" (SC4: Focus group of Professors from the Faculty of Political and Social Sciences of Milan's Università Cattolica del Sacro Cuore, 22 February 2018) - can offer all the interpretation and communication tools that will help them find their place in today's global society and inside the universal Church.

The present chapter, authored by two members of the Coordinating Committee, is based on the information and suggestion collected through a public consultation launched at the beginning of the synodal process (started $15 \mathrm{Janu}-$ ary 2018 and continued until 1 April 2018).

\section{On the Eve of a New Era: Milan as a Cultural and Religious Melting Pot}

It is safe to say that the Church, through its many articulations -from parishes to Caritas facilities spread all over the diocesan territory, from religious congregations to Catholic movements, from the various associations to the numerous charismatic figures of the Catholic world- has been, in the past few years, one of the main actors on the Italian and Milanese reception scene (Chapter 10). It is surely thanks to the valuable experiences and competences gained over time that the local Church has managed to be actively helpful, despite a social climate marked by the aftermath of the economic crisis and by the growing concern towards migration and its impact on local communities. As proof of the Church mobilization, we can observe that the asylum-seekers hosted by parishes and accommodated in facilities associated with religious organizations, at the beginning of 2018, account for as many as 2,360. Besides, Catholic aid centers are also offering sanctuary to those who are officially denied asylum but who remain in the country of arrival illegally and have no other access to essential goods. Both newly arrived and long-time foreign nationals are today the main group of people who look for help in centers providing assistance to the poor - which is paradigmatic of the different needs of a society that is dealing with the consequences of an instability affecting not only the labour market, but social relations too. ${ }^{5}$ Finally, the Church has always been there for people in need, even during the recent refugee crisis, in both formal and informal spontaneous ways. For example, by arranging Italian language courses in

4 From now on, we will use the acronym sc (Synodal Consultation) when referring to the documents either written or collected by the Synodal Coordinating Committee between 15 January and 1 April 2018. When available, the exact date was indicated.

5 Caritas Ambrosiana - Osservatorio diocesano delle povertà e delle risorse, La fatica del fare comunità di cura. Un'indagine presso i centri di ascolto della Caritas Ambrosiana. $16^{\text {th }}$ Report on poverty in the Diocese of Milan, November 2017. 
the local parishes, by organizing collections to help immigrant families, and by encouraging private citizens to either welcome migrants in their own houses, or-just to give an example- accompany them to their doctor's appointment or to the offices of the public administration, whenever they have to go.

As many observed during the synodal Assembly, it was the Ambrosian Church's hard work, as well as its pragmatism, that actively inspired the whole Catholic Church in its constantly prompt and generous responses to the different issues that need to be tackled. Moreover, all the Christian believers and all the members of the clergy who volunteer to take care of refugees and migrants act on behalf of the Church as they follow the example of the "good Samaritan" who helps strangers regardless of who they are. However, a corollary of this somewhat extraordinary capability to cause mobilization is a substantial lack of awareness of the profound changes that the migration issue is also introducing to the Church.

It is worth noting that, long before the refugee crisis started dominating the reception system, as well as the public debate on the short- and long-term impact of migration, Milan had become one of the main cultural, linguistic and religious melting pot in Italy and in contemporary Europe, too. ${ }^{6}$ The sharp rise in the number of foreign nationals -an eightfold increase over the course of thirty years, i.e. 800,000 foreign residents as of today- has led to irreversible transformations in the ethno-cultural composition of Milan's population, as well as to the creation of many national and religious minority groups. Their considerable size has indeed modified the city's "public" profile, even if integration models -such as those dealing with occupational segregation- often make them quite invisible in social contexts. For instance, the first foreign community in the rankings in terms of presence on the metropolitan territory is the Filipino. As it is a very large community, it can be compared to a medium-sized Italian city, with over 40,00o residents only in the municipality of Milan. Besides, the beginning of the Filipino immigration process can be traced back to many years ago (the average migratory seniority is twenty years) - which is reflected in a large second generation and in an incipient third one. The same kind of observations can be made about many other national groups, as they are crucial in the outlining of Milan's current and future configuration, also because of their different migration patterns. In fact, some are largely male-dominated, some others have a clear prevalence of women; some are

6 In order to further examine this phenomenon, see the documentation available on the Synod website. Cf. especially: Come l'immigrazione ha cambiato la Diocesi ambrosiana interpellandone la capacità di guardare al futuro. In this document, you can also find the sources of the data discussed above. 
characterized by temporary and circular migration, some others by long-term settlements sometimes ending up with the acquisition of the Italian citizenship, which, in the province of Milan, reached in 2016 an amount of over 16,000.

Reflecting the high transformative potential that migration has, there are data documenting how advanced its stabilization process is, with a migrant presence configuration becoming more and more family-based, a large proportion of migrants' children attending schools (i.e. over 160,00o foreign pupils) and, most notably, a high incidence of newborns with a migratory background (28\% of babies born in Milan have foreign parents, and $37 \%$ have at least one foreign parent) - which is crucial in determining the generative potential of a Diocese that is somewhat growing older and older. However, there are also data showing how migrants leaving their countries either alone or with their families finally enjoy a fair amount of "success" (e.g. through the achievement of employment stability, the purchase of a house, or the start of a small-sized business) and reach relevant roles in the cultural and economic spheres. Indeed, the international students enrolled in the universities of Milan amount to no less than 12,000, while thousands of foreign professionals, managers and high-skilled workers find employment in industries such as finance, fashion, design and healthcare. It is safe to say, in fact, that Italians tend to forget that migration is characterized not only by people moving away from the southern countries of the world to look for a better life, but also by the so-called transnational hyper-bourgeoisie, i.e. a population that is part of an international network and whose behavioral and consumption patterns -along with its lifestyle, expectations and needs- are paradigmatic of a global interconnected society and are the result of social relations and changeable personal/professional life choices.

"The Church acts through the power of the Holy Spirit, not by law": Challenges and Opportunities Posed by the Religious Pluralism

By focusing our attention on religious affiliations, we can see that migration flows have not only provoked a growth of all minority religions, but have also triggered three phenomena, which have all proven meaningful for the future of Milan and the Ambrosian Church.

\subsection{An Identity Challenge and an Opportunity for Interreligious Dialogue}

The first phenomenon, which is the most emphasized in the political and media debate, is the growth of Muslim residents, who are an estimated 270,000 over the Diocese territory. 
Such phenomenon, as observed during the consultation phase, has crystallized both the concern -with reference not really to security issues and jihadist fanaticism (which many do not consider as a high risk), but mainly to the identity issue- and the opportunity for an interreligious dialogue, as expected by Cardinal Scola (the predecessor of the current archbishop), who centered its episcopal ministry on how to reach this goal.

Muslims, in a way admired for the diligence with which they observe fasting and offer the daily prayers during Ramadan, are nevertheless emblematic of how hard interethnic coexistence can in fact be. To some, they represent the threat of a potential "clash of civilizations": the relationship between men and women -and especially the role of women in the Islamic culture-, is one of the most critical aspects affecting the perception of a social and cultural divide, or even incompatibility, between the Italian society and the apparently integrated Muslims.

On top of that, it is the presence of Islamic immigrants that fuel people's hostility towards immigration -hostility that must be explained from the broader point of view of the transformations occurred in the Italian society (SC: Focus with Movimento Terza Età, 16 March 2018). First of all, an ageing population; then, a large-scale unemployment, which affects most of all young people (who sometimes end up leaving Italy or being exposed to the "unfair competition" of newly-arrived migrants); a public debt accumulated over the years and subtracting resources from redistribution policies; the transformation of values and lifestyles, as well as the undermining of the local religious identity, which turns out to be inadequate to deal with other religious traditions (such as, first of all, the Islamic one), often interpreted by their followers in a more orthodox way. Some also act on the paradox according to which

it is easier to recognize and respect the traditions of other religions (...) than the Christian one. Today, this happens because of an overall false sense of decency that somehow compels people to choose not to seem racist over looking like devout observant Christians. (sc: Young and Adults Group AC, Deanship of Missaglia)

Furthermore, if we move from a collective level to a more private one -for example, when it comes to dealing with our ${ }^{7}$ children's marital and friendship choices or, more simply, with the "excessive" presence of Muslims in schools or in our neighborhoods-, the aspiration to behave in compliance with the dictates of the Christian doctrine collides with a widespread concern for the

7 In this text we use the terms "our" / "us" to refer to the indigenous (Catholic) long-term resident population. 
possible problems that any relationships with those who are "too" different from us can cause.

However, these exact circumstances can become fruitful opportunities to "measure" our own faith and rediscover its contents. It is crucial to underline, in particular, the opportunity to search for connections, such as some specific aspects and values of a religion that are considered as to be universal and that, for this reason, can also be shared by those who originally have different religious traditions (see also Chapter 15). In order to find those connections, in fact, we have to focus on what unites, and not on what divides -and such aim is achieved by cultivating ecumenical dialogue, by helping the needy, by praying at the same time or in the same place (sc: Marceline Sisters of Albania, 1 March 2018), and finally by promoting those figures who, because of the "universal" character of their spirituality, can attract other cultures and religions (sc: Friars Minor Capuchins of Varese). It also fundamental to point out that dealing with people who show a great attachment to their original religious traditions, also because of their migrant status, can be a stimulus for Catholic believers. ${ }^{8}$ Lastly, it is important to remind us all that only through a direct interpersonal relationship we can fight prejudice:

If you do not want to meet the other people and you do not move away from your personal disinformation, you will express your judgment on the "types of religion", but you will not be able to really see the people behind them. (sc: Focus group with students from Università Cattolica, 22 March 2018)

\subsection{A Spiritual Challenge and a Chance for the Development of Ecumenism}

The second phenomenon is the "appearance", on the Milanese scene, of the Orthodox Christianity (whose followers are estimated to be over 100,000), most of all thanks to a large presence of women from Eastern Europe.

8 See, for example, the testimony of this religion teacher: "Once, in the classroom, I asked Catholic and Muslim children to discuss the traditional festivities of their religions. To my great surprise, this emerged: Muslim children talked with joy, pride, and sometimes nostalgia, about the typical festivities of their country, also recounting the profound meanings behind each festivity; Italian Christian children, who represent the Christianity of the West, showed a warm faith and barely expressed the profound meaning of Christmas and Easter, boiling Christmas down to receiving gifts". Also see the testimony of a university professor: "I must say that, on several occasions, some questions posed by the brothers and sisters of other religions made me feel ignorant about my faith and pushed me to fortify my ability to "justify" my belief". 
As a reflection of the concentration of Orthodox (female) immigrants in definitely sui generis jobs (especially home-care assistants), this minority has long remained in the shadows until some caregivers (who, in Italian, are usually referred to as "badanti", which is a term that has a rather stereotypical connotation) started showing up for Mass, discreetly and silently, usually to accompany the elderly they assist or because there are no Orthodox churches in the surrounding area. The Italian term "badante" (from the verb "badare", to care for/to tend to) on the one hand intends to evoke the gratitude of the Catholic community for the carer's precious contribution (which can also be found in the choice of dedicating one of the meetings conducted by the Archbishop in the Cathedral during the 2018 Advent Sundays specifically to them); but on the other reveals the tendency to consider them not for who they are, but for what they do, in both the social and the religious space. As a result, they are stripped of their own individuality, as well as of their own faith, in order to place them in a specific professional category and therefore making Orthodox immigrants who do not share the same work destiny even more invisible.

Finally, the initiatives promoted to cultivate ecumenism -in particular the Week for Christian Unity- do not manage to be organized properly and end up being attended by very few people, thus becoming completely irrelevant to the pastoral practice of each parish community. With very rare exceptions, there are no significant relationships either with individual believers or with the organized communities. ${ }^{9}$

And yet, the awareness of the contribution that the Orthodox presence can bring to the rediscovery of a more authentic spiritual dimension of faith has emerged several times during the consultation; for the benefit of all the faithful and, in particular, as many observed, for the benefit of the clergy, "meeting other Christian Churches, such as the Orthodox Church, and start an ecumenical dialogue with them can make the consecrated people rediscover the essence of their lives" (sc: Daughters of the presentation of Blessed Virgin Mary in the Temple).

\subsection{A Pastoral Challenge and a Chance for Learning How to Engage in Self-Reflection}

The third phenomenon that we are going to discuss is the arrival of Catholic migrants. It is in fact on them -who are the living testimonies of the new

9 Among these exceptions, we can mention the initiatives undertaken by the Ecumenical Group of the Cantù Deanship, the fruitful work of the Council of Christian Churches of Milan, and the various initiatives promoted -in collaboration with the Orthodox Church and other Christian Churches- by the Community of Sant'Egidio. 
Church from the people- that the attention must be focused, in order to grasp the ambivalence -which sometimes becomes indifference- of the attitudes towards migrants.

Thanks to immigration, there are about 233,00o "new" Catholics either gathered around the so-called ethnic chaplaincies or included in the everyday religious activities of the parishes of the Diocese or practicing their religion more sporadically.

The first observation that can be made after the consultation is that, despite the statistics documenting their conspicuous number, many parish communities do not really seem to notice the presence of Catholic immigrants, probably because of the different lifestyles and the different places of worship they attend, as immigrants either prefer liturgies and places reserved for them or manage to go to church without really being noticed - except in specific moments, such as the baptism of a newborn. However, even on these particular occasions they are unlikely to affect the life of the community in which they live.

Called upon on the occasion of the Synod, various parishes and deanships realized that they did not know much about their parishioners of foreign origin, and for this reason decided to conduct a "census" to estimate their number and better understand their situation. So far, in fact, the interest towards migrants has been shown especially in relation to their needs, without any distinction between Christian immigrants, agnostics or people of other faiths (see Chapters 10 and 12). Indeed, they are seen as the recipients of a "special" pastoral care -the "pastoral care of migrants"- a sort of "compensatory" pastoral care (to draw a parallelism with the compensatory pedagogy once used in schools) for those who have some "deficits" (at least of a linguistic nature) to tackle. It has also been noticed that some people tend to adopt attitudes of superiority towards them, or even feel annoyed by them, or suspicious, when for example their behaviors are considered to be unsuitable for holy places. One of the most striking case is that of an immigrant who used to help collect the offers during Mass and who was accused of trying to profit by it. Finally, we also need to mention the tendency to dismiss their religious manifestations as folkloristic.

As can be noted, there is some sort of resistance and a general sense of mistrust when considering giving tasks and responsibilities to the Christians coming from other nations, consequently recreating within the Church that subordination process that takes place in the labor market. Migrants' sense of inferiority, caused by their social role, is expressed in their propensity to selfghettoization and gives rise to stereotyped expectations also as far as their roles in parochial activities are concerned. On top of that, not only are common 
believers not valorized; consecrated people, too, find themselves "filling the holes" in the religious orders that are short of vocations, and are appreciated only in relation to the tasks that their accomplish, especially if they are in the field of assistance.

The suburban areas, however, are significantly affected by the problems caused by an either poor or marginal immigration, and for this reason are deeply aware of how migration flows are indelibly transforming the composition of the neighborhoods, of the school populations, of the needs of the inhabitants, and of the ecclesial community. We can cite the parishes of via Padova, of the Barona neighborhood, and of the deanery of San Siro, which are areas where it is easy to observe situations of hardship, along with a few episodes of "interracial" conflict, but where, at the same time, it is possible to record experiences of mobilization from below, as well as practices of neighborliness and projects promoting the inclusion of newcomers and the construction of the common good. In many respects -and with a prophetic meaning-it is the "suburbs" (in a sociological rather than a geographical sense) that turn out to be authentic laboratories of interethnic coexistence in which the future of the Ambrosian Church is being written. As stated in one of the documents received,

(...) the most intense context where the dialogue takes place is the one involving the most socially disadvantaged Italians, as immigrants find themselves in their life contexts. The care-givers deal with the elderly; workers find jobs in the least qualified areas of work, such as construction or manual work; students attend schools on the outskirts of the city; and the buildings are public housing buildings. (sc: Deanship of Gallarate)

Contrary to the threat of a "war between the poor", it is precisely in this context that the concern to not relegate foreigners to the margins of the community is manifested, along with the concern to not disregard their forms of popular piety. It is always in this context that, to quote the words of a priest, the focus is on overcoming formal "liturgical languages and styles, not limiting ourselves to proposing our traditions and celebratory forms, but being willing to be contaminated" (sc: Priests of the San Siro Deanship). It is not by chance, in fact, that it is more usual, here, for immigrant traditions to find space in the liturgy, for foreigners to sit in pastoral councils and among educators in the oratory, for catechesis to be "multi-ethnic".

Very often, however, immigration is not perceived in its transformative quality, and not even as an opportunity for self-reflection, i.e. an encouragement to 
reflect on both the present and the future of the local Church. In describing the evolution of interethnic relations, the assimilation solution is frequently used in order to indicate a non-problematic coexistence, where foreigners -who are not many and who are, at times, barely visible in the public space- are not considered as such anymore (as it used to happen during the internal migrations of the past decades), except in some critical situations when people are looking for someone to blame. To cite just a few examples, the extraordinary linguistic richness that immigration creates -easily seen in the Milanese cultural industry- cannot be found in the liturgy of the Ambrosian churches, which are basically still monolingual (and mono-cultural) -if we do not take into consideration the celebrations held specifically for foreign communities. In fact, Milanese Catholics are still not fully aware of the evangelization potential of immigration, ${ }^{10}$ and that is because they tend to focus more on issues such as the violation of human rights or religious persecutions. Also, many migrant parents are not happy with the idea of raising their children in a society they perceive as "morally neutral" and, for this reason, different from what they had imagined when they were planning their journey to the cradle of Christianity. Besides, we can see how "old" and "new" Milanese (especially those who have left fundamentalist and oppressive regimes behind) need to be educated in the values of secularism -conceived in its deepest form- and of religious pluralism (see in this regard Chapter 11). We finally have to note that the needs, the skills and the potential of the aforementioned hyper-bourgeois are only partially recognized by the structures of the local Church. And that the same can be stated for the contribution of dozens of priests and other religious people coming from all over the world who are members of religious orders or work in diocesan institutions or in local parishes.

\section{It Is Sowing Time: The Reasons behind the "Church from the} People" Synod

To break the inertial mechanism with which the ecclesial body was responding to the many stimuli described above and, at the same time, to make the Christian communities, as well as the whole Diocese, become a reflection of their ongoing transformations, the new archbishop Mons. Mario Delpini decided to

10 In this case, too, there are some significant exceptions. For example: "The evangelization of the poor through charity is one of the clearest signs of the Kingdom of God. When this is achieved, it creates a dimension of positive and joyful proclamation that generates hope" . (sc: Community of Sant'Egidio, 30 March 2018) 
use an instrument that was typical of periods of major change (such as in St. Charles Borromeo's times or, more recently, in Cardinal Schuster's). That instrument was the Diocesan Synod.

The Archbishop's declared aim for the "Church from the people" Diocesan Synod was to help the Diocese recognize the changes that are taking place in its corpus in order to remain faithful to the task that defines its identity - and that is serving as the instrument through which the Christian faith and God's message of love for everyone is announced.

\subsection{Inside a Tradition}

The Synod has not been created out of the blue. It was in fact the result of a process of dialogue started in the immediate post-war period. The Ambrosian Church has always paid attention to any changes taking place in the world around it, and has always tried to understand them and adapt to them, or even criticize them in an attempt to correct them. Cardinals Montini, Colombo, Martini, Tettamanzi and Scola have always done everything they could to keep the Christian faith alive in the urban context of Milan, which has always been marked by profound transformations. With the help of many Christians, they used to listen to every question they were asked, they tried the best to respond to all the requests for help they would receive, and they would do anything in their power to fulfill the hope of those wishing for a happy life - starting from the poorest and the marginalized.

The "Church from the people" minor Synod is part of this tradition. The Ambrosian Diocese participates in the synodal journey in order to remain faithful to a specific trait of the Church, which is the will to be there for those who look for help and for those who feel alone or struggle to decipher the meaning of every major change. The Ambrosian Church sets out on this synodal journey also to discover more about the Holy Spirit's plans inside these changes, and to offer everyone the fruit of this comprehension exercise, as it strongly believes that a more mature and incarnated Christian faith will create a brighter future not only for the ecclesiastical institutions and its pastoral bodies, but also for the people living in Milan and the institutions contributing to the development and the governance of the city.

\subsection{An Intense and Quick Journey}

The Synod was defined as "minor", since it focused only on a chapter of the text to be updated. It was active for a relatively short period time, as it began in November 2017 and ended on St. Charles Borromeo'day, 4 November 2018 - the connection with this holy pastor is deliberate: he was in fact the one who gathered the first synods to keep the ecclesial body up to date with what had been 
introduced by the Council of Trent. It activated an articulated and well-planned process that focused on listening and on dialoguing, thus leading the ecclesial body to a better understanding of the changes it has been experiencing, as it knows that the destiny of grace that God has in store for us must be sought inside those changes.

Many thought that such a short time would be not enough to complete such an important task, i.e. understanding and interpreting all major changes. In truth, the appointed time frame is perfectly in line with the code of communication typical of our contemporary culture: a longer time frame would in fact let the synodal theme fall behind many other urgent issues characterizing the life of individuals and communities; on the contrary, a shorter time can help focus more on what is really at stake. The Synod is conceived as a moment of awareness based on the idea that the changes the Christian communities need to make are above all cultural. It will take years to really put into action the insights and the signs of openness that the minor Synod has been showing within the Diocese. ${ }^{11}$ With this in mind, everyone was welcomed to participate: women and men, lay people and clergy, individuals and families, people living a consecrated life and the new ecclesial realities, members of the Ambrosian Church for generations as well as newcomers, Christian believers and anyone else who is willing to take part in the construction of the Milan of tomorrow. The theme on which the Ambrosian Church has to express itself was well defined: as the title "Church from the people" clearly suggests, we must observe how, in a time of social and cultural changes, the operation of gathering of people that has been carried out for centuries by the Holy Spirit here in Milan is undergoing significant transformations.

\subsection{Milan, Church from the People}

For this mission to be successful, a Synod was certainly necessary. As it had been necessary in 1995, at the time of the 47th Synod promulgated by Cardinal Martini - although it is fair to say that the evaluation of its results did not concern such a wide scope as today. The Ambrosian Church was invited to go back to a particular chapter of that Synod, the one dedicated to Pastoral of Foreign People. As the reader can easily guess from the title, there was a clear need for this text to be adapted to the changes that have been taking place in the world around. The Ambrosian Church was asked to reinterpret this section of the Synod by focusing on a more specific dimension of its life and of its actions, i.e. the one that expresses its catholicity. This means understanding that, because

11 At the beginning of 2019, a special commission was established in order to implent the Synod's indications. 
of the arrival of new people, the Ambrosian Christian communities have not only activated reception services and integration paths, but have also tried to encourage a fraternity among different people.

The purpose of this synodal path is eminently pastoral. Every Christian community and every ecclesial reality was invited to react to the questions posed by the synodal path. As a result, the Church was expected to become more aware of its catholicity and to do its best to translate this awareness into pastoral choices that are agreed upon across the diocesan territory. A Church from the people that, day by day, will be able to spread more serenity and more hope for the future even to the rest of the social body. The Ambrosian Christian communities will in fact have tools to better comprehend the very complex social and cultural situation that many tend to define, in a quite simplistic way, as "the phenomenon of migration". A Church from the people, a Church gathered in a Synod with the aim of remaining faithful to its Ambrosian identity that is, as in the days of Saint Ambrose, in continuity with its spirit.

\section{"The Church is bigger than our fences"}

Migration scholars are very fond of the "mirror" metaphor. Indeed, if many themes and problems raised by the multi-ethnic and multi-religious transformation of Milan had already been outlined during the 47th Synod, we need to point out that although the immigrant population, today, has dramatically grown (and, with it, its incidence on the demographic profile of a city with an aging population), there is an increased awareness -at least among the "experts"- of the fact that the destinies of the city and of the Ambrosian Church are indelibly intertwined with that of immigration (if this is the word that we want to keep using when referring to it). Taking into consideration this mirror function is therefore a precious opportunity for a Church -and for a societythat wants to reflect on its own future.

To evoke one of the themes that has already emerged, but that we will not be able to discuss any further here, we will not be surprised to hear that the "good" integration (and the good coexistence) will not be built by migration policies (or, at least, not only by them), but rather by "good politics" itself, with both a government and a governance system truly oriented towards the common good. In this context, immigration helps lay bare the problems, bring a different perspective from which to look at things, and show the risk of "wars between the poor", especially where the social protection systems are flawed and where a sense of insecurity is more widespread: "The presence of people who migrate creates issues that must be faced" (sc: Focus with students from 
Università Cattolica, 22 March 2018). As some explicitly claim, and as seen in many other documents, a renewed spirit of evangelical testimony displayed by Christians will not however be enough to solve the many problems that are affecting all the communities. For this reason, it is necessary to develop the idea of a society that is able to meet the need for more sustainable processes, and it will be in this framework that the management of new arrivals and the enhancement of the contribution of migrants will be placed (sc: Focus with Movimento Terza Età, 16 March 2018). Catholics will have to do their part in order to achieve this goal. ${ }^{12}$

In this light, the consultation has produced, we believe, some significant results. We will refer to them in a necessarily brief form, without further discussing the richness of the contributions received, and we will try to clarify some crucial matters, which indicate the emergence of the awareness of how Milan is, and must learn to think of itself as, one of the focal points of a truly universal Church, a reflection of a globalized society and, at the same time, the expression of catholicity at its deepest. Such awareness cannot help but make the Church come to terms with some implications regarding the various dimensions of its identity: its everyday life, its organization, its pastoral care, and its theology.

\subsection{The Dimension of the Everyday Life}

From the everyday life point of view, it is above all the young people who are confronted with this reality. They naturally live their destiny as global citizens, growing side by side, in a city that has become cosmopolitan, with peers who are more and more distant from the myth of ethnic, cultural and religious homogeneity on which our state communities had been founded. This reality, however, sounds less familiar and less "natural" to the adults and to the older generations, although they are more prone to religious practice and to participation in Catholic associations, therefore being more exposed to the values of Christianity.

This generation gap clearly suggests that the need to keep the traditions alive, the reluctance to include the novelty brought by immigration, and the issue of cultural identity, end up hiding the Church's effort to renew itself, to propose a liturgical and pastoral offer that is able to intercept the expressed and latent needs of the diversified population of the Diocese of Milan, with its variety of individual and family lifestyles. The decrease in the number of

12 An indication that was first taken into account after the establishment of the Commission for the common good that will support the Archbishop in the analysis of "social matters". 
faithful who regularly attend Mass (particularly true for younger age groups), and an even more dramatic reduction in the amount of people who receive the Sacraments (especially baptism) is the most eloquent sign of this problem that, if not addressed, can become a real risk..$^{13}$ Nevertheless, this problem is also a providential warning:

In our pastoral condition of parishes built in suburban areas and full of different people and cultures, it is clear to all of us that if we (authors' note: the Western Church) shut ourselves down we will surely disappear. The phenomenon of the drastic reduction in baptisms and marriages among Italians is well known. Further discussions on this interesting phenomenon could be carried out during the Eucharistic assemblies or while taking catechism classes. (sc: Priests of the San Siro Deanship)

The coincidence in time between the diocesan minor Synod and the world Synod dedicated to young people is perhaps a prophetic sign, which tells us of a Church -and of a society-called to renew itself, to "regenerate itself", through the activation of channels of dialogue, exchange, mutual fertilization between different generations. On the one hand, we can see that young people, as "exiles of the real meaning", have at heart the desire to overcome every inadequate behavior or language, and feel inevitably close to foreign people for being on the margins of a Church that they would like to be able to

walk "with" them and to be more close to reality; a Church that is a "home" for everyone, and not just a club of friends; a Church that is open to the risk of encountering others. (sc: Focus group with students from Milan's Università Cattolica, 22 March 2018)

On the other hand, we have the elderly who, in order to fully play their role as witnesses/educators and as guardians of the values of humanism and catholicity, express the need to be the recipients of the "care" of the diocesan Church and of a project designed and created specifically for them (sc: Focus group with Movimento Terza Età, 16 March 2018).

13 "Our communities run the risk of becoming self-referential and closed in on themselves; their traditions could end up being excessively glorified to the detriment of a true Christian experience, continuously kept alive by the Holy Spirit; our habits, our order, our certainties could finally prevent us from "being fertilized and enriched"”. (Pastoral Council of the Pastoral Community Paul vi, Paderno Dugnano) 


\subsection{The Organizational Dimension}

At the organizational level, the Church's universal feature manifests itself in the numerous ethnic chaplaincies that welcome the faithful who come from other places, in the increasingly heterogeneous composition of the religious congregations present in the area, and in the presence of foreign priests who support the Diocese and the various parishes in their daily work. As stated in one of the contributions received, today the Church from the People is outside the door (sc: Presbyteral Assembly, Varese, 6 March 2018) and is linked, not only ideally, to the Ambrosian Church by a story of reciprocity. ${ }^{14}$ However, the potential of this transformation still remains largely unexpressed.

Certainly, the most attentive observers can understand the precious role that foreign religious people play in all those areas where the presence of foreign users is increasing and, in particular in places of suffering, such as hospitals and prisons. They also make everyone more aware of the conditions of people living in other continents, showing us that we are actually "fortunate faithful". Besides, we can observe that the testimony of foreign religious people can attenuate the frenetic activism of the Ambrosian Catholicism, asking for more meditative and internalized ways of living one's faith:

The sisters who have come from the Asian continent, who are more inclined to meditation and prayer than to activities, remind the people of the Ambrosian God, who is active and frenetic, to the foster the values of interiority, of relations and of Christian creativity. (SC: USMI Council, Archdiocese of Milan integrated by two non-European sisters, 22 February 2018)

In this regard, the presence of the Eastern-rite Catholic believers, such as the wide presence of the Orthodox Church in its various national declinations (Romanian, Russian, Bulgarian, Serbian, Greek, and also Coptic), make the Western declination of the Christian faith -very intellectual and very simple from a liturgical point of view- wonder how the gift of a God who reveals himself and who makes himself present by entering into a relationship with all dimensions of the human person should be lived today, in the current culture.

14 SC: "It is with affection and gratitude that we want to remind you that some of PIME (the pontifical institute for foreign missions) missionaries who came to us were from this parish: since they helped us learn more about the Christian faith, today we, too, would like to give our contribution to the local Church". (Sister Giustina Kalko, Shanti Rani Community, Valmadrera, 25 March 2018) 
Once again at an organizational level, we can see that the missionary orders present in Milan, and their communities, carry in their imprinting a desire for openness that makes them inclined to collaboration as well as capable of "inhabiting change", as they reflect on the different ways that migrants have to live their religion. We can also observe that the Milanese missionaries scattered around the world can show the sensitivity of a Church that is a minority and that cannot impose itself, but that can still do little things that will not make it to the news, "but that will make a difference for those who live next to me" (sc: Father Paolo Ceruti, PIME missionary of Hong Kong); a Church that can become an intermediary between believers of different cultures and societies, as the Church really knows what it means to feel like a stranger (sc: Marcelline Nuns in Albania). Finally, the ethnic chaplaincies, often accused of contributing to the self-segregation of immigrant communities, start to be seen in a different light, thanks to the Synod, as they become important actors in the construction of the new "Church from the People", linking not only the immigrant communities and the Ambrosian Church, but also -and above all- the Ambrosian and the universal Church. Together with other religious orders, they "pose to the Ambrosian Church the challenge to achieve a universal opening" (sc: Community of Comboni Missionary Nuns).

However, as it is evident in this testimony, the universality of the Church is measured, first of all, by the ability to see in each person a Son of the only Father. It is precisely in this context that much still needs to be done, even within the boundaries of the Church:

There is much to be improved even within the ecclesial community, which sometimes is not aware of the fact that acting on behalf of the Church means to act on behalf of the Spirit and not just by the rule of law; that being part of the Church means catholicity and openness to the world. Even though officially proclaimed, there is no real perception of the absolute equality of men as children of God in the Son - children who all carry, deep down, the image of the Father, who all wish to love and to be loved, who all have the same needs and the same feelings, and who are able to think and make decisions. (sc: Italian Conference of Secular Institutes)

\subsection{The Pastoral Dimension}

Moving on to the pastoral plan, as many have stressed, it is a matter of changing from "doing for" to "doing with" the migrants. Of course, we are not at year zero. The consultation was also an opportunity to measure the richness of the 
initiatives "generated" by the territories (from intercultural theater workshops to Italian language courses - which became, over time, places of confrontation and mutual re-evangelization). The opportunity offered by the Synod to make these projects known to a larger audience was much appreciated and managed to trigger a process of mutual fertilization. However, as we mentioned above, it is not easy for many to make room for immigrants and for their ways of living the faith and the liturgy - thus preventing their potential for evangelization and regeneration from being exploited. "Doing for" is certainly an expression of altruism and generosity, but when it turns into paternalism "it hinders the achievement of an authentic human relationship" (sc: Lay volunteers of the Missionaries of Charity, Baggio, 3 March 2018).

In any case, we can list a number of specific suggestions. Some are quite "obvious" and recurrent, like the hope that during the liturgical celebrations more space could be granted to migrant believers, for example by choosing them as readers (even if their linguistic competences are not perfect); by saying prayers in a foreign language; by introducing songs from their tradition; by presenting "their gifts" during the offertory; by sharing the celebration of the typical festivities of their countries of origin; by including some contributions in foreign languages in the parish bulletin; and by translating the leaflets for Mass and the various notices. Besides, it would also help if there could be a less ethnocentric approach during catechism classes; a mutual explanation of the meaning of the respective devotional practices; an effort to rethink the language and cultural patterns of the basic pastoral care; a more punctual reference (for example in homilies) to the Christian values and their concrete declination in the relationship with others (which must always be inspired by the principles of respect and equity); a valorization of the Pentecost events as tools to understand the current Church in the paths of education to the faith; the inclusion of non-European Saints in the liturgical calendar; greater appreciation of the foreign priests of the Diocese; preaching by using narrative and experiential dynamics; choosing prayers that are universally comprehensible and that actually give voice to what is happening in the world; implementing international mobility schemes (on the model of the Erasmus project) for new priests and religion teachers; promoting the study and the teaching of African and Latin American theology, as well as the Orthodox theology; offering courses on the different religious and liturgical traditions, inside and outside the Christian world, to pastoral workers and to all the faithful; and finally rethinking the ways in which

Catholicism has expressed itself: the Western modality, exported as the best one by the European missions of preservation during the colonial 
expansion, should be open to the changes historically brought by the different cultures. (sc: Diocesan pastoral Council, 24-25 February 2018)

As summarized by another contribution,

we need to go from choosing to receive to choosing to meet; when receiving people, the relationship between those who welcome and those who are welcomed is not equal; on the contrary, when we meet people, our differences are recognized and valued as a gift and we all walk together carrying each other's burdens. (sc: Deanship of Cagnola, March 2018)

\subsection{The Theological Dimension}

Finally, as for the theological dimension, the challenge is to learn to reread the experience of faith, at the personal and at the community level, in light of the presence of Christians coming from other places and of believers of other religions, as well as in view of the growing number of agnostics and other people seeking alternative ways to express their spirituality. The importance of this challenge is effectively summarized by this testimony:

The initiative of the Feast of the Christian Peoples helped us reinvigorate our faith; despite all the limitations encountered, it helped us understand that we are not superior, and that the Church is greater than what expected by its boundaries - which can be affirmed not directly for sociological reasons, but because of the original plan of God who wants all peoples to participate equally in the communion with his Son, Jesus Christ. (sc: San Siro Deanship)

As we have already pointed out, it is first of all the "suburbs" that will grasp the regenerative scope of this challenge. Conversely, by virtue of their experience marked by precariousness, many immigrants represent the "existential peripheries", namely the places where the Lord primarily manifests itself, according to the theology enunciated by Pope Francis. ${ }^{15}$ In this perspective, there are many reasons behind immigration's potential for evangelization, especially if we consider that many of its protagonists have dramatic stories to tell, all marked by a lot of suffering and persecutions - thus encouraging us to seek a new socio-demographic, economic, political and democratic balance, as well

15 To further read about Pope Francis' theology, see: Cozzi, A., Repole, R., \& Piana, G. (2016). Papa Francesco. Quale teologia?. Assisi: Cittadella. 
as to deal with the ethical aspects of political choices, of the relations between countries, and of our daily behavior. In broader terms, there is a strong need to promote an intercultural approach, which invites us to put people and their relationships with other people at the center of attention, with each person meant as the "flesh of Christ". "We must not forget that the Church's task is first and foremost that of taking care of human relationships" (sc: Lay volunteers of the Missionaries of Charity, Baggio, 3 March 2018). In its most authentic meaning, inter-culture should give us the chance to look beyond people's countries of origin, on which we tend to focus too much, and

to simply favor human relationships: we are all different persons, and we know it, but we can try to get to know each other and get together as human beings in order to enrich ourselves. (sc: Families of different nationalities from the Migrant Pastoral, Baggio, 24 February 2018)

It is only at this point that the authenticity of the Christian message can be grasped:

We need to see people just as God sees them; therefore, the main focus should not be on immigrants, but on how we look at people, which should be in the same way as God does. (sc: Pastoral Council of the Deanship of Vimercate, 19 February 2018)

A message that, by its very nature, does not involve any distinction between migrants and non-migrants:

Like the first Christian community in Ephesus, we have the opportunity to discover an even greater value to our faith, which is true when there is an authentic sharing and a felt reciprocity. This practice of a more attentive catholicity starts from the awareness that speaking of "foreigners" and of "migrants" is deeply improper (as it emerges in the Old Testament, the whole Church was born from the Jewish-Christian announcement) and creates what can be defined as the population "of the people", which is determined by God's plan for all humanity. It is in fact the universal Church that will be able to seize the new opportunities for enrichment and for an authentic evangelization that will come along, and it will do so through the creation of new relationships, which will closely follow the Christian message and which will be strongly inspired by the commitment of the incarnate Word. (sc: Pastoral Council San Vittore Martire parish) 


\section{"Seeing people as God sees them": Implications for the Pastoral} Care and the Future of the Ambrosian Church

A first fundamental declination of this perspective is the way in which the Ambrosian Church should deal with migrants, in particular when it comes to the theme of spiritual accompaniment. The logic of interculturality, to which the Synod has further attributed the concept of "hybridization", can help the single Christians and all the communities remember that at the heart of the Church's birth and growth there is a true encounter between people. This allows them to see the presence of Christ in other people, as well as the gift that the Spirit offers to their faith, together with the need that they all have to support each other in the search for the only Father and in the understanding of God's plan for everyone. Thanks to the Synod, several Christian communities found out they had not been offering what migrants need the most: a spiritual accompaniment and support, as well as the possibility for them to feel in communion with God and "at home" even here, where they often feel in a foreign land. Such discovery manages to solve many problems concerning the relationships between natives and newcomers, thus preventing the latter from being considered as simple users of the services provided by the Catholic parishes and communities:

Helping these brothers grow humanly and spiritually means to make them aware of their potential ability to offer a service to others. (SC: USMI Council, Archdiocese of Milan integrated by two non-European sisters, 22 February 2018)

The Church can consider itself as open to the people not only if it manages to make these people feel accepted, but also if it helps them keep in contact with their place of origin, their culture, their language, their traditions and their religions. (sc: Father Paolo Ceruti, PIME missionary of Hong Kong)

A second, and even more important, declination of this perspective is the encouragement to recognize, and realize, the connection between unity and variety, as well as the idea of the "body of Christ as a unity in diversity", both in history and in the Church's life. ${ }^{16}$ The Synod allows to decline the principle of "pluriformity in unity", taught in recent years by the Magisterium of Cardinal Scola. It is a matter of interpreting the differences in celebrating, in praying, and in bearing witness to one's faith as many different ways of expressing the

1 Cor 12, 19-20, 27. 
same faith, the one that has been given to humanity, and that has been nourished by the Holy Spirit. Out of all the contributions from the consultation, many of them go in this direction:

We could also mention other examples drawn from the same narrative: people who, despite belonging to different cultures, feel united by the common Catholic Faith and by the wish that this Faith will not remain closed in a tabernacle, but will instead inundate every aspect of our life. (sc: CL Varese)

However, it is in particular the field of consecrated life that leads the way in this experience:

The communities that live a consecrated life, made up of people of different ages and of different social and cultural backgrounds, all throughout history have tried to embody the Father's plan to let all human beings be part of one big family united in love, without erasing any of their differences. Moreover, it is in the care of the weakest that we can see the inclusive and missionary nature of the Christian faith. (sc: Daughters of the presentation of Holy Mary in the Temple)

Our community life in itself is a sign of an inclusive and unconditional mutual acceptance that speaks of a single family with a single Father. Through community life, through a spirit of acceptance for all and by praying with everyone and for everyone, we can show people that we are the sons of the same Father (...). Our charisma brings the experience of other rites to the Ambrosian Church (...) and can help welcome other ways of praying and behaving, bearing in mind that, in the Church, there is room for everyone. (sc: Community of Comboni Missionary Nuns)

The daily "effort" of our communities to experience interculturality as an opportunity to grow in love and trust is one of the gifts that the consecrated life can offer to the Church, especially today. We feel the encouragement to build a communion in communities made up of sisters from different cultures, thus showing that a conviviality of differences is completely possible. (sc: Consecrated of the Forlanini Pastoral Unit, 22 March 2018)

As we notice by another testimony, it is from the orders of consecrated (and cloistered) life that a precious -yet unexpected-teaching is passed on to the Diocese: 
The efforts that we make day by day -all together as a choir or in silencewhen we have to blend our voices in one single song of praise, is what we believe to be our contribution to the journey that the Diocese is making in the search for a spirit of communion among any cultural, social and ecclesial differences. (sc: Observation by the Benedictine Nuns of the San Benedetto Monastery)

Finally, a third declination of this perspective is the encouragement to question ourselves, to reflect on the profound meaning of being a Christian today in the city of Milan, which is a city that is constantly changing. At this point, we can really grasp the deep intention of the Synod, the fundamental reason behind its proclamation: when confronted with the social and cultural changes around them, the only adequate response that Christians can give to themselves as Christians is that they, too, have to change; they have to change their institutional subject and they have to create (by asking the Holy Spirit) new ways to be part of the Church today. As cleverly observed by some from the world of education:

Living in a plural society, characterized by the coexistence of different faiths and cultures does not have to be a problem neither for Christianity nor for the Catholic Church. It used to be that way for the very first communities of believers, and it still is in many nations of the world. At times, it may even be seen as a providential opportunity, as it encourages Christians to deepen their faith: this is what Peter used to suggest by warning about the importance of always being ready to give reason for one's faith. (sc: Catholic religion teachers of the Besta Institute of Higher Education in Milan)

Significantly, one of the most recurring aspects is the awareness - either acquired or strengthened when facing the "different"- of the need to regain "our" Christian identity through the attempt to deepen the faith and to define the personal and the collective identity of local believers. As stressed by many participants, only through dialogue can the local culture survive and open up to change.

Many have observed, or at least perceived, that the re-appropriation of one's own Christian identity is the first step towards an authentic dialogue with otherness; conversely,

the difficulty of starting a dialogue is not necessarily due to the diversity of cultures; it rather depends on the weakening of our Christian values. In 
our society we tend to hide any possible reference to our faith, and that starts being true ever since our children's early education (...). Therefore, people should be braver when it comes to living and bearing witness to their faith in the world. (sc: Deanship of Carnago)

Finally, as a result of the encounter with other people, Ambrosian Catholics' faith becomes stronger and more aware of its universality. Contrary to what is usually believed, a dialogue is possible not only when one tries to acquire or broaden his/her knowledge of other faiths:

I think that Catholics can really open up to others if they do become more aware of their own Catholic identity - which has nothing to lose (but much to gain) if compared with the other faiths, as they encourage us to further understand the reasons for our faith. (sc: Observation by a Religion teacher)

As it appears, the most tangible -and perhaps the most profound-result of the minor Synod is the acknowledgment of the need for a process of reChristianization of the Ambrosian Diocese, namely the need for the Ambrosian Church to keep up with the present time in order to remain a friendly face of Christianity, close to the people's hopes and needs, in line with the model of popular Catholicism inherited from the past. As some priests and some parochial realities have pointed out, in order to achieve this goal, Catholics from other cultures and nations can be extremely helpful:from some communities of foreign Catholics, in fact, indigenous people could learn "a more authentic faith, a deeper devotion and a more lively liturgy" (sc: Deanship of Legnano, 14 February 2018), "the same careful attention to the liturgy and the Eucharistic celebrations, as well as a true sense of fraternity" (sc: Cassina de' Pecchi Pastoral Councils). Ultimately, to quote the words of a group of priests, it is necessary to

focus more on that essential, on the Gospel and on the Eucharist, and therefore on the basics of our faith, in order to catch sight of the aforementioned openness towards "the others". (sc: Meeting of priests in San Pietro Cusico di Zibido San Giacomo, 15 March 2018)

We can finally observe that the Synod has strongly promoted the need for a reChristianization, that is a re-appropriation of the past through a path of selfreflexivity, always with an eye towards the future and towards the new age that the current surge in migration flows is powerfully announcing. The Synod has in fact encouraged the adoption of a dialogical style, which -as the results of 
the consultation phase clearly demonstrate- can help raise awareness of the multiple implications of the transformations taking place around us. Finally, by supporting the adoption of a participatory approach, the Synod has given the communities a chance to reflect on their plans for their future, as well as on the future of the next generations and of the Ambrosian Church -a Church made up of people where there is, indeed, "room for everyone". 